\title{
Improving Students' Environmental Awareness Using 3R Principles
}

\author{
Muhammad Nizaar ${ }^{1, *}$, Sukirno $^{2}$, Djukri $^{3}$, Sintayana Muhardini $^{4}$, Mas'ad $^{4}$ \\ ${ }^{1}$ Faculty of Mathematics and Natural Science, Yogyakarta State University, Indonesia \\ ${ }^{2}$ Faculty of Economics, Yogyakarta State University, Indonesia \\ ${ }^{3}$ Faculty of Mathematics and Natural Science, Yogyakarta State University, Indonesia \\ ${ }^{4}$ Faculty of Teacher Training and Education, University of Muhammadiyah Mataram, Indonesia
}

Received August 27, 2020; Revised October 5, 2020; Accepted November 1, 2020

\section{Cite This Paper in the following Citation Styles}

(a): [1] Muhammad Nizaar, Sukirno, Djukri, Sintayana Muhardini, Mas'ad, "Improving Students' Environmental Awareness Using 3R Principles, "Universal Journal of Educational Research, Vol. 8, No. 11B, pp. 6146-6151, 2020. DOI: 10.13189/ujer.2020.082251.

(b): Muhammad Nizaar, Sukirno, Djukri, Sintayana Muhardini, Mas'ad (2020). Improving Students' Environmental Awareness Using $3 R$ Principles. Universal Journal of Educational Research, 8(11B), 6146-6151. DOI: 10.13189/ujer.2020.082251.

Copyright $\bigcirc 2020$ by authors, all rights reserved. Authors agree that this article remains permanently open access under the terms of the Creative Commons Attribution License 4.0 International License

\begin{abstract}
People's concern toward environmental sustainability is decreasing; it is proven by a large amount of waste that is not handled correctly. The training is needed to accustom every people to manage their garbage at home. The science learning process function in the classroom needs to be maximized by training students to process waste into more useful products. This research aims to improve students' environmental awareness through waste management training according to the $3 \mathrm{R}$ principle. This research used a quasi-experiment one-group pretest-posttest design. Data were collected using a questionnaire, observation, and documentation. The total number of samples is 39 students of junior high school, and data analysis uses paired samples t-test, with an error rate of $5 \%$. The result shows that activity for managing waste can be used for organic fertilizer, handicraft, decorative flower made of paper, flower vase, etc. They have a significant influence on students' concern for the environment. This condition indicates that students' environmental awareness by training students to process waste using the $3 \mathrm{R}$ principle can reduce excessive household waste production. The $3 \mathrm{R}$ principle begins with identifying and sorting waste to the manufacturing process of the product. Student-made products are useful for their use and even for sale.
\end{abstract}

Keywords Environmental Awareness, 3R Principle, Household Waste, Useful Product

\section{Introduction}

Waste is a classic pollution problem that is currently faced in some areas. Waste volume increases, while residual waste resulting from urban citizens' consumption is not easily decomposed, especially plastic. The increase in plastic quantity waste will cause serious pollution problems. Urban waste is produced from consumption, industrial activity, or agriculture, and farming. The most pollutant source is from the household; [1]. This reality reflects the people's attitude that does not care toward the environment [2]. Various efforts have been conducted by government or environmental organizations to train society's ability to manage waste into useful products [3]. However, the community has not yet accustomed to managing their garbage at home.

Waste management in households must be sorted before disposal, namely between rubbish that is quickly rotting and does not rot easily. The awareness of the Indonesian people to sort household waste is still very low. Based on the research of Susongko \& Afriza [4] that the percentage of people who do not sort waste is $81,16 \%$. As many as $10,09 \%$ of the community stated that they had sorted waste, it is not reused, and $8,75 \%$ of households have carried out waste sorting. Some sorted are reused as compost, given to other parties, sold, recycled, and used as livestock. 
Environmental awareness is an attitude and action that always strive to prevent damage to the natural environment around it and develop efforts to repair ecological damage [5]. Environmental awareness is formed from three components: the cognition component, which is related to beliefs, ideas, concepts; the affection component related to one's emotions, and the psychomotor component related to behavior [6]. Based on the three parts of environmental care, the meaning of environmental care is referred to as environmental preservation behavior based on self-awareness in taking concrete actions for environmental sustainability.

Waste processing training is essential for developing students' environmental awareness. The developing environmental awareness of students is shown in the way students throw garbage in the trash [5]. Environmental awareness indicators consist of receiving, such as paying attention and thinking about the conditions that occur in the surrounding environment, responding, namely providing answers to pollution problems, valuing, including inviting others to discuss and work on solutions to environmental issues, responsibly, related to bear all the risks and impacts of the actions taken. [5,6].

Awareness of waste hazard or skill in managing waste is needed to be taught since early childhood. School as a place to develop students' character needs to be optimized in its function as a place to train waste management. The students will know how to manage waste if they are continuously taught and trained. For instance, garbage is reprocessed into an artwork, resell, reuse, and turned into organic fertilizer[7].

The way to solve pollution is to reduce, reuse, and recycle (3R) principles that students can easily do at home and anywhere. Waste management using $3 \mathrm{R}$ principles is the way of managing waste to reduce, reuse, and recycle. Reduce means to reduce the potency of waste increasing, reuse means to use proper garbage again, and recycle means to manage waste into useful products [8].

Some recommendations of previous studies show that it needs integration of environmental education and waste management activity in educational institutions done directly both in the learning process by the teacher or indirectly by an outside party. In this way, students will be more active $[9,8]$, students can be pleased, and the awareness for the environment will increase [10].

Teaching how to manage waste through $3 \mathrm{R}$ principles can be carried out through discussion forums about the environment, project-based activities in class, by separating organic and inorganic waste to be recycled [11]. Waste management using $3 \mathrm{R}$ principles is not only used for education; the 3R principle can also be applied in industry, community environment, development project, etc. [12]. All those fields use $3 \mathrm{R}$ principles to decrease waste volume from its production activity or goods usage. Reduce, reuse, and recycle principles contain activities done by the students themselves in their daily activities. The description of waste management through $3 \mathrm{R}$ principles is explained in Figure 1.

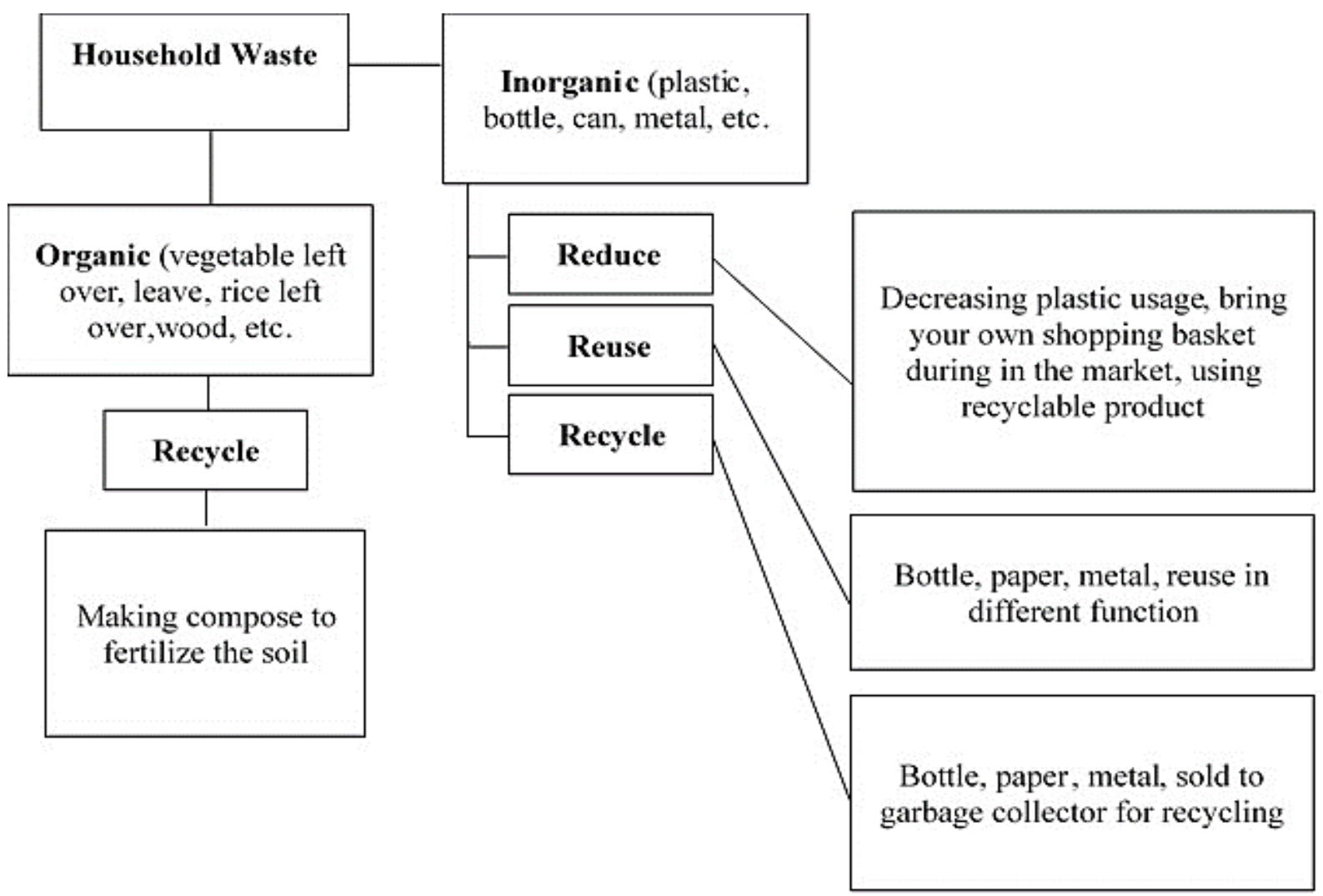

Figure 1. Ways in Managing Household Waste with 3R Principles 
The scheme above becomes teacher reference in teaching and training the $3 \mathrm{R}$ principles to manage household waste at home. Teaching 3R principles can instill students' concern toward environment perseverance at once. Reduce, reuse, and recycle waste management principles refer to garbage character categorization, organic, and inorganic waste. Organic waste in the form of residual food, vegetable, and wood can be destroyed quickly. Hence it needs the recycling process, so it is routed for being used as compost. Inorganic waste is hard to be destroyed, such as plastic, glass, or metal. It needs to be conducted to reduce, reuse, and recycle to reduce waste usage, re-utilize, and recycle.

Instilling concern toward the environment is vital to be done earlier because it will influence self-discipline in maintaining hygiene and environmental sustainability in daily life $[13,14]$. Practice in managing waste at school is expected affect to students' concern toward environmental sustainability. Through the class's learning process, teachers can train students to manage waste according to the 3R principles to foster students' respect toward the environment. However, concern toward environmental hygiene is not meeting the expectation yet, the students have not been accustomed to utilizing used goods and household waste, so all garbage types tend to be dumped right away without processing it first.

\section{Materials and Methods}

The research was quasi-experiment research using a one-group pretest-posttest design to test the significance of training to handle waste using the $3 \mathrm{R}$ principle toward students' environmental awareness. The research design is as follows.

\section{1}

Explanation:

O1: Students' environmental awareness before given treatment in managing waste training using $3 \mathrm{R}$ principles (pre-test)

O2: Students' environmental awareness after given treatment in managing waste training using the $3 \mathrm{R}$ principle (post-test)

$\mathrm{X}$ : Treatment in managing waste training using $3 \mathrm{R}$ principles

Quasi-experiment was carried out to the students of junior high school with a sample number of 39 students. Data collection used a Likert questionnaire scale that is contained questions related to environmental awareness. The questionnaire consists of five environmental awareness indicators: attentiveness toward waste issues, availability in handling waste, curiosity on managing waste, an effort to manage waste, and responsibility to maintain cleanliness.

Data analysis used paired samples t-test on 5\% significance level to test zero hypothesis stated, "there is no significant difference in students' environmental awareness before and after being given treatment." Before conducting analysis, data were treated with prerequisite analysis, which is a normality and homogeneity test.

\section{Results and Discussion}

\section{Research Result}

\section{Types of Student's Activities in Handling Waste}

The student's handling of waste was guided by the natural science teacher of Junior High School because the natural science object study was on environmental pollution. The waste handling activity done by the student is explained as follows.

\section{Selecting waste (reduce)}

This activity aimed to distinguish organic and inorganic waste. Students were asked to bring waste from home as used bottles, cans, paper, metal, vegetable waste, rice waste, etc. In the school, the teacher instructed the students to sort out which garbage included organic and inorganic groups. Students do these activities in groups. The garbage categorized into organic waste and inorganic waste is then processed in the next activity.

\section{Making organic compose (recycle)}

This activity aimed to make solid and liquid compose. Solid compose was made from vegetable waste and rice waste. Whereas liquid compose was made from rice wash leftover. The product made by the students was as shown in Figure 2.

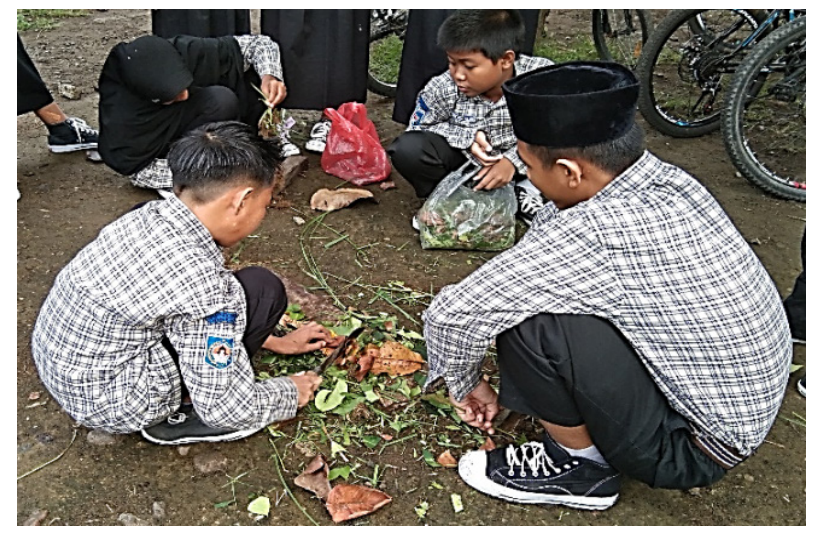

(a) Process of making organic fertilizer 


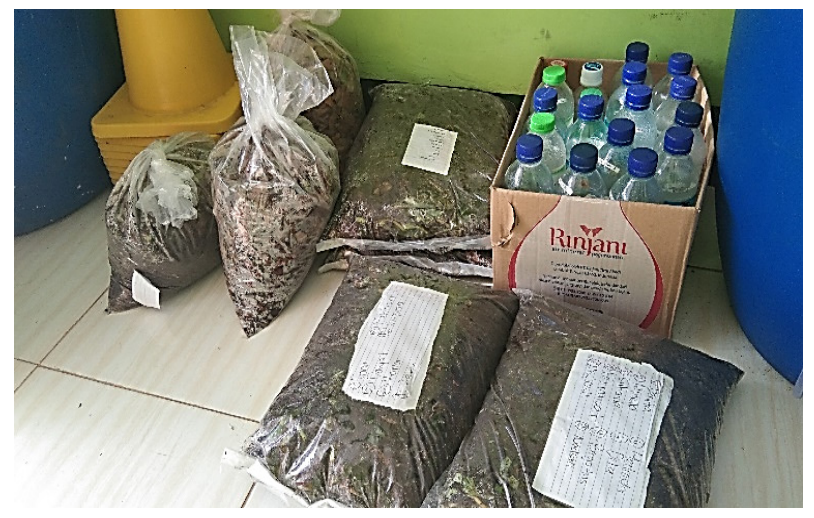

(b) Solid and liquid organic fertilizer product

Figure 2. Activity in Managing Organic Waste into Organic Fertilizer

Solid-liquid fertilizer made by the student was packed after the decaying process for two weeks. Simultaneously, liquid fertilizer from rice wash leftover can be used to watering plants after one week of stored.

\section{Making handicraft product (reuse)}

This activity aimed to handle used goods into a more useful product. The students' types of products were flower vases from bottles, decorative photo frames made of sand and shells, soap baskets, decorative flowers made of paper and plastic. The example of a product made by the students was shown in Figure 3.

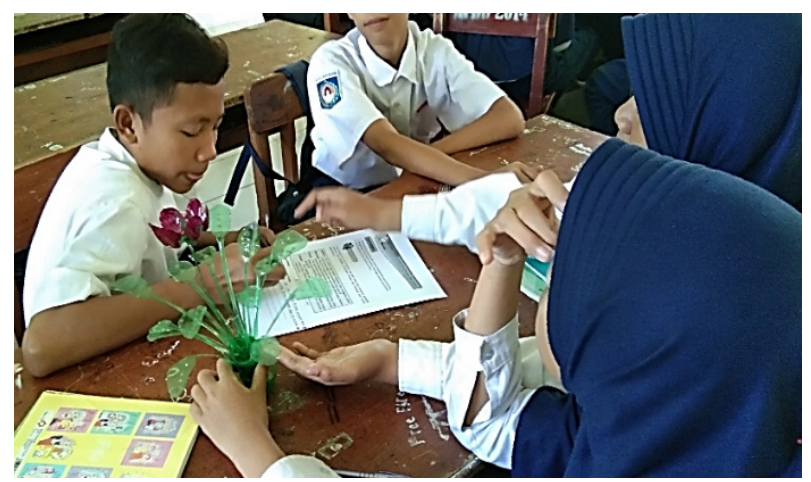

(a) Process in making handicraft product

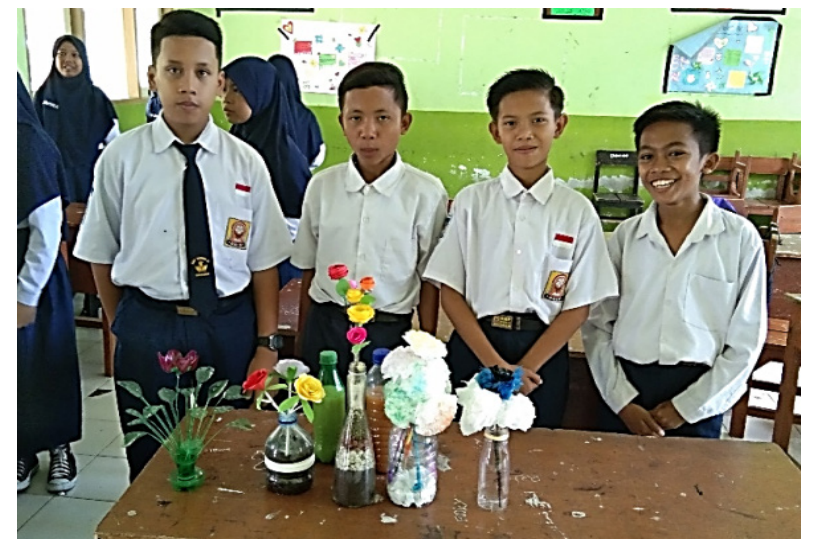

(b) Handicraft product

Figure 3. The activity of Making Handicraft Product from Waste

Teachers get tutorials on how to make crafts from the
YouTube site. The teacher displays a video on how to make a product so that students can follow how it is made. However, students are also given the freedom to design their own desired products.

\section{Student's Environment Awareness Before and After Being Given Treatment}

The following is presented a description of the environment awareness questionnaire result before and after being given the treatment of handling waste training using 3R Principles.

Table 1. Description in Students' Environment Awareness Questionnaire

\begin{tabular}{|c|c|c|}
\hline Aspect & Before Treatment & After Treatment \\
\hline Mean & 41.13 & 46.72 \\
\hline Variance & 21.430 & 17.524 \\
\hline Minimum & 33 & 36 \\
\hline Maximum & 49 & 53 \\
\hline
\end{tabular}

Table 1 showed the mean value after being given treatment was higher compared to before treatment, variant data before treatment was higher compared to after treatment, minimum value, and maximum value after treatment was higher compared to before being given treatment.

Descriptively, there was a mean increase as much as 5.59 after being given treatment. Enhancement significance of mean value after being given treatment was tested using paired samples t-test on 5\% significance level. Test of normality data before and after treatment was carried out using the Kolmogorov-Smirnov test. Value of normality probability test (sig. 2-tailed) about 0.200 . The score showed that data were distributed normally because it was $>0.05$. The homogeneity test of variance based on mean was carried out through Levene's test. The probability test value of variance homogeneity was derived as much as 0.290 . The score showed variant data was homogeny because it was $>0.05$.

Based on the prerequisite test analysis, it was stated that data were distributed normally, and the variant was homogeny in nature. Therefore, a parametric statistic test was carried out. The result of the paired sample t-test from SPSS statistics is shown in Table 2.

In conclusion, if the probability value (sig. 2-tailed) showed a value of $>0,05, \mathrm{H} 0$ was accepted, and Ha was rejected. On the contrary, if the probability value (sig. 2 -tailed) was $<0.05$, then zero hypotheses were rejected, and the alternative hypothesis was accepted.

The result of the t-test showed that the mean score after treatment was higher compared to before treatment with a mean margin as much as -5.590 . Value of t-test was derived -12.692 and significance value (sig. 2-tailed) was as much as $0.000<0.05$. This showed that zero hypotheses were rejected, and the alternative hypothesis was accepted. In other words, there was a significant influence of handling waste training using $3 \mathrm{R}$ principles toward students' environmental awareness. 
Table 2. The Result of Paired Samples Test in student's Environment Awareness

\begin{tabular}{|c|c|c|c|c|c|c|}
\hline t-Test & Mean & Std. Deviation & Std. Error Mean & $t$ & df & Sig. (2-tailed) \\
\hline Pretest-Postest & -5.590 & 2.750 & 0.440 & -12.692 & 38 & 0.000 \\
\hline
\end{tabular}

\section{Discussion}

Waste handling carried out in a group by students started from identifying classification for organic and inorganic waste. Waste selection activity was a kind of reduced principle aimed to separate garbage according to its natural characteristics. Later, it was utilized in more useful products.

The students' type of product from organic waste was liquid organic fertilizer from rice wash leftover and solid organic fertilizer made from vegetable waste, leaves, dry grass, and cow dung. The fertilizer was very useful in fertilizing the soil. Meanwhile, inorganic waste products are flower vases from bottles, decorative photo frames made of sand and shells, soap baskets, decorative flowers made of paper and plastic.

Giving treatment of handling waste training using $3 \mathrm{R}$ principles showed a significant influence on students' environmental awareness. Before treatment, the mean score of environmental awareness was as much as 41.13, while the mean after treatment was 46.72. The mean enhancement was significantly based on the t-test result. Enhancement in environmental awareness was a form of students' attentiveness enhancement toward waste issues, students' availability in handling waste, and students' intention for responsibility toward environmental hygiene. In this research, gender distinction is not seen as the cause of environmental awareness enhancement because gender differences do not significantly influence students' environmental awareness [15].

This research is in line with the study stating that environmental cleanliness internalization value can be carried out by instilling awareness on waste, thinking of garbage, and practicing waste handling [16]. The way of instilling environmental awareness will influence the student's knowledge. Students' behavior in the school can be formed through the law of effect states that behavior followed by satisfaction consequences will be repeated. On the contrary, behavior followed by punishment consequences will not be repeated. The research result answers students' environmental awareness on environmental issues still low [17]. One way that can be done is through actual activity in handling waste into useful products $[18,19]$. The activity can decrease society's habit of dumping waste into the gutter, side of the road, and various places that are not appropriate [20,21].

This research stressed that student's character changes were carried out through cognitive aspect and learning activity that trained skill and real activity also influenced the student's behavior changes. Therefore, character building in schools is needed to balance cognitive, affective, and psychomotor aspects.
Teaching students' concern toward environment is not just taught to be aware of environmental issues but also be active in participating environmental protection. Those ways can be integrated into school activity $[22,8]$. Teaching models that can be conducted are to give reading materials with environmental theme, ask students to mention potential action they can do to minimize environmental pollution, and perform real action to decrease environmental pollution [23, 24].

\section{Conclusions}

Based on the research result, it was showed that activity in handling waste using $3 \mathrm{R}$ principles could influence students' environmental awareness. The $3 \mathrm{R}$ principle is applied through integration with science learning in three types of activities, they are sorting waste into organic and inorganic groups as a reduce principle, making handicrafts from used goods as a reuse principle, and processing organic waste into solid fertilizer and liquid fertilizer as a recycle principle.

The types of products the students made consisted of organic fertilizers from vegetable waste and water from washing rice, handicraft products in the form of flower vases from bottles, decorative photo frames made of sand and shells, soap baskets, paper and plastic flower ornaments. Students are given the freedom to make the desired products according to the types of waste abundant in their respective environments. Students who are given treatment in the form of training to process waste into useful products positively impact increasing awareness of the environment. This kind of activity is more meaningful than lectures to instill concepts in the classroom.

Handling waste using the $3 \mathrm{R}$ principle not only instills awareness of the impact of waste pollution problems on students, but also trains real behavior in reducing household waste in everyday life. Waste processing activities need to be carried out more frequently in schools through integration with the teaching and learning process and integrated with school extracurricular activities so that students' environmental awareness develop properly.

\section{Acknowledgments}

Our sincere gratitude and appreciation are given to the teachers in SMPN 21 Mataram city and the headmaster to contribute during the research process. Moreover, our gratitude is also for the students who were willing to follow instructions to manage waste as in the activity plan. 


\section{REFERENCES}

[1] T. Karak, R. Baghat, P. Bhattacharyya. Municipal solid waste generation, composition, and management: The world scenario. Critical Reviews in Environmetal Science and Technology, Vol. 42, No. 15, pp. 1509-1630, 2012.

[2] A. Desa, A. Kadir, F. Yusooff. Environmental awareness and education: A key approach to solid waste management (SWM)-A case study of a University in Malaysia. In L. F. M. Rebellon (Eds.), Waste management-An integrated vision. IntechOpen. pp. 101-112, 2012. Online available from https://www.intechopen.com/books/waste-management-anintegrated-vision/environmental-awareness-and-education-a -key-approach-to-solid-waste-management-swm-a-case-stu dy-of-a.

[3] K. Joseph, S. Rajendiran, R. Senthilnathan,M. Rakesh. Integrated appriach to solid waste management ini Chennai: An Indian metro city. Journal of Material Cycles and Waste Management, Vol. 14, No. 2, pp. 75-84, 2012.

[4] P. Susongko, T. Afrizal. The determinant factors analysis of Indonesian students' environmental wareness in PISA 2015. Jurnal Pendidikan IPA Indonesia, Vol. 7, No. 4, pp. 407-419.

[5] Y. Ye, Y. Shih. Environmental education for children in Taiwan: Importance, purpose and teaching methods. Universal Journal of Educational Research, Vol. 8, No. 4, pp. $1572-1578,2020$

[6] S.C. Helvaci, I. Helvaci. An interdisciplinary environmental education approach: Determining the effects of E-STEM activity on environmental awareness. Universal Journal of Educational Research, Vol. 7, No. 2, pp. 337-346, 2019.

[7] M. Aliman, Budijanto, Sumarmi, I.K. Astina. Improving Environmental Awareness of High School Students' in Malang City through Earthcomm Learning in the Geography Class. International Journal of Instruction, Vol. 12, No. 4, pp. 79-94, 2019.

[8] I. Deveci, S. Cepni. The effect of entrepreneurship education modules integrated with science education on the entrepreneurial characteristics of pre-service science teachers. Social Work Research Journal, Vol. 15, No. 2, pp. 56-85, 2017.

[9] N. Huda,N. R. Dewi. Pemanfaatan kertas bekas bungkus rokok untuk meningkatkan keaktifan siswa dalam membuat rangkaian listrik 3 in 1. Unnes Science Education Journal, Vol. 1, No. 1, pp. 44-49, 2012.

[10] S. Patonah, S. B. Rahardjo, Carl, Sajidan. The potential of outing class activities to enhance environmental awareness for elementary school pre-services teacher. International Journal of Pedagogy and Teacher Education, Vol. 2, No. 1, pp. 1-6, 2018.

[11] P. Karyanto. Non-curricular strategies in the implementation of education for sustainable development in three prominent green schools in Indonesia. IOP Conference Series: Journal of Physics. https://doi.org/10.1088/1742-6596/1241/1/0120 35, pp. 2-6, 2019.
[12] B. Vidyasekar, K. G. Selvan.Implementation of 3R Principle in Construction and Demolition Waste Management. International Journal of Innovative Technology and Exploring Engineering. Vol. 8, No. 12, pp. 667-672, 2019.

[13] R. P. Situmorang, S.D. Tarigan. Cultivating students' environmental awareness by creating bottle garden in school: A qualitative study. Jurnal Pendidikan Biologi Indonesia, Vol. 4, No. 3, pp. 263-270, 2018.

[14] G. J. Thomas. Pedagogical frameworksin outdoor and environmental education.Journal of Outdoor and EnviromentalEducation, Vol. 23, No. 2, pp. 173-185, 2018.

[15] L. L.Ezverenzha, S. R.Pramana, K.A. Sulis. Environmental awareness of junior high school students in terms of grade and gender. Jurnal Pendidikan IPA Veteran, Vol. 2, No. 1, pp. 13-24, 2018.

[16] C.D. Licy, R. Vivek, K. Sarita, T. K. Anies, C. T. Josphina. Awareness, Attitude and Practice of School Students towards Household Waste Management. Journal of Environment, Vol. 6, No. 2, pp. 147-157, 2013.

[17] T. S. Emiru, D. K. Waktola. The environmental awareness of higher education student and the implications for the Paris Climate Agreement, empirical evidence from Ethiopia and USA. International Research in Geographical and Environmental Education, Vol. 27, No. 3, pp. 216-233, 2017.

[18] R.D. Anazifa, Djukri. Project-based learning and problem-based learning: Are they effectivetoimprove student's thingking skills. Jurnal Pendidikan IPA Indonesia, Vol.6, No.2, pp. 346-355, 2017.

[19] B. El-Batri, A. Alami, M. Zaki, Y. Nafidi. Extracurricular environmental activities in Moroccan middle schools: Opportunities and challenges to promoting effective environmental education. European Journal of Educational Research, Vol. 8, No. 4, pp. 1013-1028, 2019.

[20] M. Desfandi, E. Maryani, Disma. Building ecoliteracy through Adiwiyata program (study at Adiwiyata school in Banda Aceh). Indonesian Journal of Geography, Vol. 49, No. 1, pp. 51-56, 2017.

[21] S. Suwarno, W. Wahidin, S. H. Nur. Project-based learning model assisted by worksheet: It's effect onstudents' creativity and learning outcomes. Journal of Biological Education Indonesia, Vol. 6, No. 1, pp. 113-122, 2019.

[22] O. N. Nwakaego, A. M. Kabiru. The need to incorporate entrepreneurship education into chemistry curriculum for colleges of education in Nigeria. Journal of Education Policy and Entreprenurial Research, Vol. 2, No. 5, pp. 84-90, 2015.

[23] L. Setyowati. Integrating character building into teaching to enhance the student environmental awareness. Journal on English as a Foreign Language, Vol. 3, No. 1, pp. 1-10, 2015.

[24] M. Nizaar, Sukirno, Djukri, and Haifaturrahmah. Wastepreneurship: A Model In Improving Students' Confidence And Creativity. European Journal of Educational Research, Vol. 9, No. 4, pp. 1473-1482, 2020. 